\title{
AN ARCHITECTONICS OF DESIRE: THE PERSON ON THE PATH TO NADA IN JOHN OF THE CROSS
}

\begin{abstract}
The strenuous ascetic that is established in The Ascent of Mount Carmel and The Dark Night by John of the Cross, frequently, and not illegitimately, is viewed as the purging of desire, but often to the extent that desire exclusively is perceived as a detrimental and negative quality. With a modest shift in perspective, this article attempts to read John through the lens of desire, rather than against it. It employs the notion of 'desireless desire', in order to describe John's final position of waiting as one that neither dispenses with an authentically human and desiring subject, nor compromises the final aim of union with God.
\end{abstract}

\section{INTRODUCTION}

Desire is solicitous. Implicit in desire is lack and need: implicit in solicitation is motion, agitation, and anxiety. The movement towards fulfilling the need - the solicitation of the desire - causes anxiety. In theology, desire, as that endeavour to solicit what is required, has long been rendered suspect. In fact, in most of the tomes of spiritual ascetics, desire is a dirty word. It indicates egoism and self-seeking avarice. Desire transgresses the threshold of the temperate and publically permissible, and travels into the regions of the permissive, the excessive, and the shameful. Desire conjures up images of the illicit and, particularly, the forbidden regions of sensual and sexual pleasure. Such an evocation of desire may appear to be precisely what a sixteenth-century Spanish Carmelite wishes to expunge. However, ask John of the Cross about what he most desires, about the pursuit of that desire, and, thus, about the necessity of taking a journey to obtain that which is most desirable, and he will answer that

Dr. F. England. Research associate. Faculty of Theology, University of Stellenbosch, South Africa. E-mail: sjotcs@yahoo.co.uk 
One dark night,

Fired with love's urgent longings

- Ah, the sheer grace! -

I went out unseen

...

With no other light or guide

Than the one that burned in my heart

$\cdots$

I abandoned and forgot myself,

Laying my face on my Beloved ("The Dark Night").

The search to fulfil the desire of "love's urgent longings" by "laying my face on my Beloved", solicits the quest to fulfil desire's lack. Notably, the sensual and sexual imagery is not muted; rather, the physicality of John's desire, like that of Bernard of Clairvaux's (Howells 2002:135; \& 198 n. 46), is accentuated. In the long tradition of Christian spiritual writings, various evocative tropes of the senses of the body and of sexual intimacy are employed as the most apposite to "coupling" with God. This, like any desire at its most engaged, is singular and focused. John's desire is for God and, not unlike the love poets of the Romantic Tradition, he laments,

When I am not with You

What life can I have

Except to endure

The bitterest death known? ("Stanzas of the soul that suffers with longing to see God").

Thus, he summarizes perfection with a centred attentiveness as

Forgetfulness of creation,

Remembrance of the Creator,

Attention to what is within,

And to be loving the Beloved ("The Sum of Perfection").

This concluding state of "loving the Beloved" is union with God, and it is a "teleological or telic" desire, because it is about "some event as an end, or for its own sake" (Parfit 2011:44; original emphasis). But there are also "instrumental" desires, desires as "means" to that end (Parfit 2011:44; original emphasis) and, more prominent within the ascetics of Christian spirituality, there are prohibitive desires that hinder and obstruct the journey towards that end. The instrumental desires as means, and the prohibitive desires as obstructions, must both be subjected to the teleological or telic desire, so that the vehicles that contribute towards obtaining that end are purified and refashioned, and the obstacles that impede the path to that end are jettisoned and discarded. Such a procedure ensures that the conducive and obstetric desires are reconfigured, and the 
pernicious and destructive desires are expelled, and that, having identified and deracinated the latter, the former, although initially contributing to the telos, ultimately are themselves transformed into one, engaged, and unidirectional desire.

If this disciplining, expelling, and ordering of desire is the aim of John of the Cross, how does he systematically establish and, possibly, achieve it? He does so, one suggests, because, in contrast with most of his contemporary students in Europe, John is exposed to Aquinas, and, as a consequence, he reads Aquinas in dialogue and dispute with Augustine, in a comparable, if less comprehensive, manner to the way in which Aquinas had read Augustine in dialogue and dispute with Aristotle (see Maclntyre 1990). For Aquinas, desire wants what is good, and desirous appetites, if they accord with reason, are virtuous and pleasurable, but if they do not accord with reason, they cause the soul to sin (Summa Theologiae, II 30 \& 32). It may be proposed that John both appropriates this conception of reasoned desire, and then extends his reflection upon unreasoned desire, for two reasons. First, he employs this understanding of desire of Aquinas's because, after his entry into the novitiate of the Carmelite Order in 1563, John studied in Salamanca from $1564-1568$, both at the college of his order and at the university, which, with Paris, Oxford, and Bologna, was rated amongst the finest (Kavanaugh \& Rodriguez 979:17; McGreal 1996:7). Rather than study the Sentences of Peter Lombard, the standard theological text from the twelfth century (Pieper 1960:95 - 99), John was required to read the Summa Theologiae. The reason that Aquinas, rather than Lombard, was taught at the University of Salamanca was because Francisco de Vitoria (c. 1485 - 1546), whilst a student in Paris, had been lectured by Peter Crockaert, who replaced Lombard's text with that of Aquinas's Summa. After his appointment to the higher chair of theology at Salamanca in 1526, de Vitoria followed the Parisian practice of his former teacher and chose the Summa rather than the Sentences as his basic text (Maclntyre 2009:106). Likewise, de Vitoria's later successor, the Dominican, Mancio de Corpus Christi, whose daily early morning hour-and-a-half lecture John would have attended in the academic year of $1567-1568$, also required his students to read Aquinas (Kavanaugh \& Rodriguez 1979:18). Second, John extends Aquinas's understanding of desire, because, as a late scholastic but also a mystic, reason and reflectively acquired knowledge is inextricable from the activity of loving, which is itself a form of knowing: amor ipse notitia est (Gregory the Great). As McIntosh (1998:70) observes,

in the tradition passing through Augustine (354 - 430) and Gregory the Great (c. $540-604)$, love and knowledge are at the highest levels utterly coinherent, 
and both Augustine and Aquinas constituted John's "coinherent" intellectual and spiritual worlds. In John's corpus, Lombard does not feature, but Aquinas does, as indeed does Augustine, and for Augustine, desire is less susceptible to the control of reason than it is for Aquinas. Augustine believed that the very power of desire's intensity can be

\begin{abstract}
an agent of unreason and self-deception ... [and] ... that our desires are inordinate in respect of their finite objects, such objects as those of the bodily pleasures, of the goods of success and the goods of friendship. And they are inordinate because they are at once expressions of and disguises for our love for God (Maclntyre 2009:28).
\end{abstract}

Accepting the telic aim of reasoned desire for the good from Aquinas, and aware of the deceptive power of instrumental and prohibitive desires for finite goods from Augustine, John maintains the importance of desire's presence in the pursuit of the soul's ultimate telos, but he reconceptualizes desire as "desireless desire", as desire that employs one kind of desire and discards another kind of desire, which is then reconfigured as an attitude of non-possessive disinterestedness, a final stage which establishes a site where that telic desire is transformed into an act of waiting. ${ }^{1}$

It is argued that, in undertaking this task, John constructs an architectonics of desire - a systematic mapping of human desires and their aims. Therefore John produces an epistêmê, a knowledge system, which, significantly, is mystical, in the sense that knowledge - knowing oneself, knowing one's passions and pursuits, and knowing God - is not simply the product of rational procedural reflection, but it is both a means to ensure, and is implicit in, the proper hierarchical ordering of one's affections, as is this proper ordering of one's affections a means to ensure, and implicit in, the very activity of acquiring knowledge itself.

\title{
2. THE CONCEPT OF THE PERSON IN JOHN OF THE CROSS
}

By retaining the telos of his system in view, John revisits the prevailing understanding of the human person, where, initially, a human person is understood to be composed of a body and a soul. However, this emerges as a deceptive dichotomy, because the soul is divided again between a

1 The desire for God and the desire for experiences of God ought not to be conflated. In this respect, see Turner (1995), whose detailed inquiry into negative Christian mysticism, and his problematizing of mystical experience, includes a chapter entitled "John of the Cross: the dark nights and depression". 
lower sense or animal soul, and a higher spiritual soul (Kurian 2000:121; Flynn 1996:260). Therefore, because the latter two are designated "soul", the division, more appropriately, may be stated as a tripartite one between a physical body, the senses, and the spirit, and where, for the purpose of probing John's anthropology and psychology, the soul itself may be conceptually abstracted, in order to perceive its function as dynamic, and able to direct itself to matters sensual or to matters spiritual (Howells 2002: $20 \& 154 \mathrm{n} .3^{2}$ ). John's task is to unite the person in a single telic desire by orientating the soul to embark upon the higher spiritual path. It is not simply as though the soul must draw the spirit into itself and discard the body, but that the soul - here, as synonymous with the human person - must purify itself by purifying both the physical, or, perhaps more accurately, the manner in which the experiences of the physical are facilitated and accommodated, as well as the spiritual aspects of itself. How may such a task be accomplished?

The body possesses five sensory organs, some of which are pairs eyes, ears, a nose, a mouth, and fingers - but the various organs only function because they are animated, or, to appropriate John's psychology and bear in mind his aim, they are 'en-souled'. The soul is in contact with the body and its five sensory organs through their operation; that is to say, a person activates the organs and, consequently, seeing, hearing, smelling, tasting, and touching occur through the activities of the lower sensory soul. Thus, these are not merely physical organs that have the capacity to sense, but organs that do sense through higher-level functions, functions of which are carried out by the five exterior bodily senses, which constitute sensing operands and employ the physical organs as conduits of their operation. Therefore, in the physical activities of sensing, something more than physical is occurring. And because something more than physical is occurring, that which is sensed through merely physical organs not only is experienced as a sight, a sound, a smell, a taste, or a sensory touch, but also is experienced as a particular view, a level of noise, a type of odour, an asperity or sweetness of taste, or a quality of emotive feeling. Subsequently, these over-determined sensory experiences, almost

2 The reference here is to 1 Thessalonians 5:23, and, in particular, the Origenist appropriation of this trichotomy of soma, psyche, and pneuma. With regard to the epistle's author, Ridderbos (1975:121) observes that Paul uses both "soul" and "spirit" to describe the inner person and, therefore, little should be read into any distinction between these two terms, and, although Wanamaker (1990: 206 - 207) agrees, he does add that the three terms do reflect a local Hellenistic anthropology. 
involuntarily, ${ }^{3}$ are configured into various transitory associations by a more interior bodily sense than those of the exterior bodily senses, namely, the imagination. But the imagination does not stabilize these images; rather, it produces and "plays" with various possible temporal configurations which have been experienced by the five exterior bodily senses. ${ }^{4}$ Consequently, when one of these fleeting imaginative configurations is reified for more focused scrutiny, that image then becomes a fantasy. ${ }^{5}$

Thus, even though the physical body possesses the organs to sense - eyes, ears, a nose, a mouth, and fingers - sensing itself belongs to the lower part of the soul. This part of the soul, which is concatenated with the physical body, possesses five exterior bodily senses - sight, hearing, smell, taste, and touch - and two interior bodily senses - the imagination and the fantasy - which receive, process, and arrange the sensed experiences in various ways, and then stabilize them. This, for John, is a function of the soul not so much as it is orientated to the body, otherwise it may be captive to the physical and to desires that may be prohibitive, but rather as the soul is inextricably linked to the body, because its "content" is the product of the exterior senses.

3 The phrase "almost involuntarily" is inserted, because this faculty of the imagination belongs to the animal soul, but it seems to echo the function of the memory, which belongs to the higher spiritual soul, and undertakes a more deliberative and archival configuration of images, and one with implications for the future. The theological virtue of hope is tied to memory.

4 It is interesting to note that Boym's (2010:27) recent expatiation on the imagination conflates John's distinctive functions of imagination, fantasy, and memory. With regard to memory, whilst not dissimilar to John, although, probably, verging closer to that of Augustine, is the following: "With the help of the imagination we can conceive of what our senses do not perceive, as if connecting the invisible within us to the invisible in the world, discovering the inner cosmos that enables us to confront the cosmos beyond our reach .... Imagination bridges not only spatial but also temporal discontinuities, connecting 'no longer' and 'not yet' as well as 'could have been' and 'might become'”. Contiguous with John's imagination, is Boym's (2010:27) statement that the "[i]imagination bridges the gulf between the visible and invisible .... It devises all kinds of 'transports' through metaphors ... similes, anamorphoses, allegories and symbols. Imagination entertains the hypothetical, moves through leaps, lapses, and ellipses and engages in double vision". With respect to the reflective function of John's fantasy, Boym (2010:27) observes that the imagination "includes a capacity for self-distancing".

5 Fantasy here must not be taken as some fantastic, extravagant, or inventive vision. Rather, the meaning coheres with its root form - phainô, to make apparent, exhibit, or appear - and therefore, fantasy may be conceptualized as "a showing", a making apparent of one of the imaginative configuration for the purposes of examination. 
The stabilized images of the fantasy provide the material for consideration by the higher, spiritual part of the soul. It is as though the soul now turns away from the functions of the senses, the experiences that they provide, and the elementary processes of selecting and ordering those experiences, to a more rational, reflective, and exacting activity, which is carried out by the faculties of the memory, the intellect, and the will.

John's use of the faculty of the memory enlarges that of Augustine's, for whom the memory was a "storehouse for images and forms" (Howells 2002:16; Aspell 1999:30), and for whom the narrative self is constituted retrospectively by means of recollection (Freeman 1993:29). ${ }^{6}$ For John, the memory actively employs images, and therefore it utilizes the interior sense of the imagination, because the latter has undertaken the prior, if cursory, action of generating images from the sensory experiences in a continual and transitory "viewing" process, possibly comparable to the sweep undertaken in cinematographic panning. ${ }^{7}$ However, the memory co-operates more closely with the imagination's more formal interior twin sense, the fantasy, because it requires a degree of image stability, in order to examine and classify the various images, and also, in order to draw upon former images or "memories". This latter procedure enables the filtering of current images through former images, and permits the assessment of former images through current ones, and, importantly, of scrutinizing and evaluating the present images, informed as they are by the past, with respect both to future general scenarios and also to specific options and

6 Thus, for Augustine, memory is also the place in which God is found "[b]ecause we find God precisely as those who have once lost him, and our search for him is therefore like trying to recollect a truth that we have forgotten" (Cary 2000:138).

7 The relationship between the images present in the imagination and the relationship of images to memory, as understood by John, is not too dissimilarly conceived by Derrida (2001:159 \& 160; original emphasis) in his address following the death of his colleague, Louis Marin. Marin had written accomplished studies on art, and Derrida's meditation was delivered at the Pompidou Centre in Paris on 28 ${ }^{\text {th }}$ January, 1993: "What is only in us seems to be reducible to images, which might be memories or monuments, but which are reducible in any case to a memory that consists of visible scenes that are no longer anything but images, since the other of whom they are the images appears only as the one who has disappeared or passed away, as the one who, having passed away, leaves 'in us' only images". But these images construct the one in whom they are located, and, moreover, they are instructive, even if, as in death, the person whose image still remains, is no longer present: "What this rhetoric of space, this topology and this tropology, miss, what this description of lack lacks, is that the force of the image has to do less with the fact that one sees something in it than with the fact that one is seen there in it. The image sees more that it is seen. The image looks at us". 
possible directions to pursue (Kurian 2000:122 \& 155-156). Therefore, memory does not simply produce sophisticated, classified, and ordered information, it also produces knowledge, but it is propriate knowledge, it is knowledge about who one is at this present moment, both in the context of a past, and also in the context of possible and probable futures. ${ }^{8}$

It is noteworthy that John breaks with the dominant concept of memory as established by thinkers both before and after him. The understanding of memory as an authentic imprint of an original event or occurrence is found from Plato to Freud, where the principal image is that of the wax seal (Bernecker 2010:217 - 218). But both neuro-biologists and cognitive psychologists have demonstrated that the understanding of memory as a passive faculty is inaccurate. Not only do the former attest to its "active" capacity if memories are to be retained, and with which the latter concur, but they also emphasize that the retrieval of memories is a constructive process, rather than the simple recall of stable content. It can be observed that John's understanding of memory coheres with the later research, and memory modulates as the person changes in time and as his or her character is being constituted. This is a conception of memory not dissimilar to the "entailment thesis" of memory, in which what is bequeathed as memory is differentially remembered, so that the act of recall is not identical to the content of storage but is entailed on it (Bernecker 2010:222-229).

Although memory, together with the intellect and the will, are spiritual faculties which are rational, it is the second faculty, which is designated both the "understanding" and the "intellect" by John, that applies the specific operation of ratiocination to the images of knowledge ordered by the memory. The intellect conducts the arguments and debates concerning what may be held to be true and trustworthy, and about what may constitute legitimate and valid knowledge or genuine and right belief. The intellect endeavours to assess information for the purposes of an holistic comprehension, so that reasons may be stated for appropriating particular beliefs, for upholding and rating certain systems of knowledge, for locating them with respect to their functions and explanatory ability, and for rejecting some beliefs and knowledge systems as lacking descriptive and explanatory power. With respect to the individual, the intellect works closely with the memory. It supplements the operation of the memory, because it includes the self-distancing, meta-reflective, and rational

8 Matthew (1995:106) has expressed this elegantly: "When John says 'memory', he means ... the person's capacity to retrieve, anticipate, possess the otherwise fleeting moment as her own; the faculty, then, of possession, of selfpossession, roughly corresponding to what we mean by 'consciousness'. It gives me my place vis-à-vis the past, but also with a view to the present ... or to the future .... It is what lets me be myself in time". 
apprehension of the self in the present, by focusing on that "present-self" in relation to the history of the self's past. But the intellect accomplishes more than that, since it rationally assesses this presently constituted self-with-a-past in terms of various open future options, by providing reasonable grounds both for pursuing certain subsequent actions and also for not undertaking others.

However, as John forthrightly states:

The strength of the soul comprises the faculties, passions, and appetites. All this strength is ruled by the will. When the will directs these faculties, passions, and appetites toward God, turning them away from all that is not God, the soul preserves its strength for God, and comes to love Him with all its might (Ascent III, 16.2; emphasis added).

No matter how detailed, sophisticated, exacting, and appropriate rational reflection may be upon the content of the memory - content which has been appropriated from the stable images of the fantasy, themselves selected from the passing flux of transitory representations in the imagination, which, in turn, are received as experiential sense data through the physical organs of the body - "it availeth nothing" without the central force of the human person, namely, the will. Crucial to enacting the results of the processes of the reason, is the faculty that, as it were, casts the deciding vote at the "convention" of the faculties, a "meeting" at which is tabled the "information" of the senses as visited and arranged, classified and ordered, stabilized, represented, and reasoned upon. The will, for John, governs the human person, and directs it to God or away from God, and not merely by pointing it towards various paths. Rather, as that most powerful faculty of the human being, it resolutely, and with concentrated and insistent dedication, pursues its aim with unremitting vigour and unceasing effort. In fact, the activity of the will is appetitive and desirous; it acts rather than merely cogitates and reasons. Therefore, it is this, the most dynamic of the human faculties that, in facilitating the reasons of the intellect, must impel the pursuit of the soul's true end. It does so by disempowering the senses of their prohibitive and instrumental desires, so that these desires are attenuated into one desire, and by turning the occupation of the memory with its own history to focus on the future, in order that the person, having discarded all that impedes that telic desire, which now, concomitantly, is an epistemic desire - a knowing stripped of all knowledge that may impede the pursuit of that single goal - then loves only what it knows and knows only what it loves. In order to achieve this telos, the soul must revisit not only the desires that impede the desire, 
but also the desires that assist in transporting the soul towards the one, singular, and ultimate desire. How is that to be achieved?

\section{DESIRING DESIRELESS DESIRE}

John plots a successive journey of nada between two other paths, which, respectively, pursue the goods of heaven or the goods of earth. The journey of nada is the journey to union with God, and it is a journey of the night. The image of night is appropriate, not merely because it coheres with the teaching that John lays down about stripping and purifying the soul of both its appetitive and intellectual attributes, but also because the goal of the pilgrimage is a teleological desire, which is understood in terms of what, ultimately and finally, is the only true desire of human persons. And it is an entirely apposite metaphor because, although this final desire may be analogous to other desires - most notably, the desire of a human lover for his or her human beloved - this desire is, in fact, unlike any other desire, in that the object of this desire is a telos in its ultimate and unqualified sense. Therefore, desire's lack or need cannot be stated in human terms. It is obscurus, it is dark and obscured, and even the instrumental desires, which, initially, may appear to aid the quest, prove, finally, on this path, to be obstacles.

\subsection{The active night of the senses}

John orders the climb up Mount Carmel through two nights, each of which has an active and a passive component (see, inter alia, Kurian 2000; Doohan 1995; Matthew 1995; Kourie 1993). The telic desire for God initially involves probing the first night of the senses, as they were established in the concept of the person above, and actively disciplining, purging, and discarding the appetitive desires, that is, not the legitimate physical need for food and drink, but the manner in which that need becomes a desire that exceeds the requirement of the person and, as a result, impedes the progress towards the ultimately desirable goal. Desires that are in the way of the desire must be jettisoned, or, perhaps stated less strongly, and yet, quite possibly, more accurately, control by the senses must be converted into control of the senses. The "mortification of the appetites" (Ascent I), of the senses, senses which operate by means of desires for what is seen, heard, smelled, tasted, and touched, involves an act of cancelling their present functions, and then reconfiguring them at another and higher level. This process converts the desire to taste and touch that which is seen, heard, and smelled, and transforms it into not possessing the desire to taste and touch that which is seen, heard, and smelled, rather than actually 
not tasting and touching that which is seen, heard, and smelled. Thus, what are removed are the desires, and not the exterior bodily senses, nor their legitimate need of fulfilment. What are discarded are the cravings, which result in the formation of the self around a hierarchy of passions and wants, rather than the constitution of the self in terms of its perfect end, so that that telos informs the "desireless" activity of the senses.

The passionate response to possessions - the joy and pleasure of owning and experiencing them, the hope and expectation that the ownership of these artefacts continues and with it the sensations that possession engenders, the sorrow and anguish experienced when their presence is denied and their pleasures obstructed, and the fear and alarm of being deprived and losing the ownership of them - is then converted into joy, hope, sorrow, and fear about the things themselves as they are in themselves - as works of creative beauty or technological ingenuity or artisanal skill - rather than about the personal investment in, and ownership of, them - that is to say, joy in the painting itself, rather than in the possession of the painting. Thus, through this conversion, through this stripping of desire, the stance of John's pilgrim has been transformed from attachment to detachment, from self-interest interestedness to otherdirected disinterestedness (Ascent III, 20). Here, it can be observed, is the earnest not merely of relating to the world, both the resources of the created order and its artefacts, without the desire to possess, manipulate, or own them for oneself, but also, and not unimportantly, the possibility of relating to other people, not as interpolations of oneself, not as receptacles of one's own projections of likes and dislikes, but as they are in and of themselves, for their own sake and not for one's own sake (see van Eck \& England 1990).

\subsection{The active night of the spirit}

The active night of the spirit begins by transforming the primary aim of the faculty of the intellect from wanting to know to wanting to trust, and the conduit of that transformation is faith. If John's "mystical theology" is innovative in its recasting of desire and "modern" in its augmentation of memory, similarly here too he presses Scholastic reason to perceive in faith less a stable state of conscious assent to formulae, than a transition to a passive acquiescence and availability, which is less an activity of knowing, than an acceptance of being known. Why is this so? It is because the telic desire is a desire for that which is beyond the reaches of human desire, and it comprises not only a will to know that which is beyond the bounds of human knowledge, but includes forms of knowledge which are beyond any possible human categories and forms of knowledge. Therefore, it is no 
accident that this night is "darker ... than the first part of the night and, in a certain way, darker than the third" (Ascent II, 2.1), and which, for John, counts as the most "radical [of the] spiritual crises" (Turner 2011:136) for the soul. All possible expressions of rational processes - that is, all logoi, as both orationes and rationes - are inadequate, and the seeker's body of knowledge is dislodged, as the known of the terra firma is converted into the unknown of the terra incognita. All the systems of intellectual apprehension and control are dissipated as knowledge, by means of faith, turns into the endurance of a singular trust. No active meditation is helpful, no visitations, apparitions, or locutions are to be entertained. Rather, the pilgrim,

[I]ike a blind man he must lean on dark faith, accept it for his guide and light, and rest on nothing of what he understands, tastes, feels, or imagines (Ascent II, 4.3),

in order that activity becomes passivity, and the instrumental desire to know is dissolved into the telic desire to be known by the only knower who possesses knowledge, and where knowledge is indivisible from the ultimate knowing being itself.

Likewise, the memory, which is a consciousness of who one is in time and in space, and through relationships with others of the past, the present, and in possible futures, is transformed into one focused hope. For the memory, with its reservoir of former images of the self, its selective views on the achievements and failures of the self, whether it enhances the former and ameliorates the latter, or, and it could be more insidious, downgrades the former and emphasizes the latter, has produced a less than truthful self. Moreover, as is evident in the active night of the intellect, the images of the divine that the memory has stored restrict God. Thus, memory as a positive repository of material that facilitates the desire to know God, also limits that telic desire to an instrumental desire, where the instruments, rather than the telos, dictate the nature of God:

Our aim is union with God in the memory; the object of hope is something unpossessed; the less other objects are possessed, the more capacity and ability there is to hope for this one object ... accordingly, in the measure that a person dispossesses his memory of forms and objects, which are not God, he will fix it upon God and preserve it empty, in the hope that God will fill it (Ascent, III, 15.1),

a final hope that must rely upon the passive night of God's bestowal.

However, in peremptory terms, John informs us that 
[w]e would achieve nothing by purging the intellect and memory in order to ground them in the virtues of faith and hope if we neglected the purification of the will through charity, the third virtue (Ascent III, 16.1).

The will is the most obdurate of faculties. Its power is extensive, commanding both the senses and the spirit, and, to some degree, itself commanded by the affections or passions, or, what would be termed later, the emotions (Kurian, 2000:161). Moreover, the will is not simply that faculty which allocates, channels, and controls the energy of the self, and directs its activity, it also is the faculty which conserves and preserves the self. In this sense, the self is "will-full", it is full of a will that wills for itself, and thus, it wages war on behalf of itself. The will remains the singular, most powerful resister of change, and it discriminates between desires that aid, and those that thwart, its own telos, which is the desire to preserve itself. However, as the most formidable instrument of opposing transformation; so too, the will may become the most influential proponent of transfiguration.

John's path demands the substitution of that telic desire of selfcleaving and self-preservation by another and final telos, namely, God. The means of achieving this redirection of the will is to re-orientate the will's goal in its act of loving. Therefore, the will is turned from love of self to that for whom John's system has been constructed. This love, although in the "active nights" it remains an operation of the seeker, now draws close to the bestowed love of the sought. And this is because, like authentic human love, love loves because it is loved - that is to say, the source of the energy of loving well is the love with which one is loved. The love of the beloved permits, generates, and sustains the love of the lover. Love, to be true love and to culminate in eudaimonia, to use Aristotle's term - a state of being well and of acting well - is loved love, it is love and well-being both as it actively is being formed and practised, and also as it passively is met, and experienced by the lover.

But precisely because both of these desires - for self and for God - may be construed as telic desires, they may claim for themselves a degree of ultimacy beyond other desires, which leads to the consideration of a critical proposal with regard to John's system. Although both of these desires may appear as ultimate desires, they may, in fact, reveal themselves to be no more than relative desires - that is, for a self that becomes dust, or for a "God" that is a fiction. And if so, then, appropriating a postmodern critique of the essentialism of subjective identity, the means to achieve the final objective of John's nada path, and the radical nature of doing so, may require progressing beyond the desires both for self and for God, 
even, it may be suggested, to the region of Gethsemane, which, following the passionate cry of Jesus for help from God (Mark 14:32 - 36), becomes a location both beyond any expectation of a response, and also possibly beyond the recovery of any form of self-understanding in a meaningful life-world, following the shattering and dispersal of this coherent self in utter desolation. This site then does not engender the reconstitution of the self or "God", but rather becomes the singular human place of the only available singular human stance, which is one of passive, dispassionate, and perdurable endurance without expectation, rather than one of expectant waiting. However, John's context and his audience may assert that such a radical reading of John's thought appears to be too extreme. ${ }^{9}$ And if that is so, then desire appears to be reconfigured in John's system, rather than discarded.

\section{CONCLUSION}

Indeed, and not altogether inappropriately, John's text of the Ascent fractures at this juncture. His exploration of the purification of the will remains unfinished, as the passive nights are awaited. But this next phase - those of the passive nights - appears, possibly, to undermine the cessation of desire, whether for self or for God. And this is because the passive waiting for the visitation of God is itself a stance of expectation, and to be expectant means remaining trapped in the network of desire desiring what one may be expecting even when no exact definition may be offered about what is expected. Nevertheless, it does appear evident that, even in the blackest darkness of John's nights, liberation from that confinement to the cell of desire is the purpose of his system. But can this be achieved? And, possibly more appropriately, is John jettisoning desire? Or is he, in fact, re-envisioning desire and undertaking an attenuated and precise recasting of it? These crucial questions and puzzles arise because the telic desire of John's thought possibly turns out to be "desireless desire", rather than no desire. It appears to be a dispassionate and dispossessive wanting, which wants only what is needful, and, for John, what is exclusively required by human beings, in order to be authentic and

9 On an atheistic reading of John, Don Cupitt (1980: 139), when Dean of Emmanuel College, Cambridge, stated that "I have more than once set philosophy of religion students to study The Ascent of Mount Carmel and The Dark Night of the Soul. 'After all', I say, 'you want to know about God, and St John of the Cross is the best. Admittedly, he is not a philosopher but a mystic. Nevertheless, if man [sic] can know God, John did. Let's look at him'. Back come the students, irritable and disappointed: 'There's nothing there', they complain. 'That's it!', I say, 'That's it!'” 
true to what they are in their very essential selves, is God. And because this is a desire quite unlike any other desire, it may be termed, "desireless desire".

Thus, just as the physics of inertia includes predetermined and uniform motion, so also, from the point of this transition, when the determined exertion of the "active nights" trips over into the neutral inertia of the "passive nights", a similar kind of single, unwilled dynamic continues. To invoke a particular image: what remains as that persistent "motion" may be viewed as analogous to the abiding pulse of a comatose patient, whose beating life signifies on the cardiac monitor no more than a "desireless desire" to live. This condition - a posture rather than an effort - silences the speech of endeavour and experience. From this moment of passive waiting onward, what may occur is more unlike than like any human experience, since it includes the bestowed coming of God in union (Turner 1995:245), an event which, if it could be condensed into a single moment, may resemble the bestowal of conscious waking upon the comatose patient.

Therefore, finally, through following John's map, desire has been so attenuated to a residuum of unwilled persistence or to, what has been termed, "desireless desire". If such a reading of John's system may be entertained, then what John constructs appears to be less the ultimate negation of desire than, instead, its reordering. Desire, as the very dynamic of being human and, moreover, as the very dynamic of the activity of a God, who goes out from its own being in love - in the Son (Matthew 1995), and in the Son and the Spirit (Howells 2002), and, indeed, to human beings in the passive nights in the desire of them - requires neither the destruction of desire or the desire not to map desire, nor the endeavour to render desire absent, but rather the incorporation of desire, and its admission as an enduring, if final posture of, presence in an architectonics of desire.

\section{BIBLIOGRAPHY}

AspelL, P.J. 1999. Mediaeval Western Philosophy: The European Emergence. Washington, D.C.: The Council for Research in Values and Philosophy.

Boym, S. 2010. Another Freedom. The Alternative History of an Idea. Chicago and London: University of Chicago Press.

BERNECKER, S. 2010. Memory: A Philosophical Study. Oxford: Oxford University Press. 
CARY, P. 2000. Augustine's Invention of the Inner Self. The Legacy of a Christian Platonist. Oxford: Oxford University Press.

CupITT, D.

1980. Taking Leave of God. London: SCM.

DERRIDA, J.

2001. The Work of Mourning. P-A. Brault \& M. Naas (Translators) Chicago and London: University of Chicago Press.

DOOHAN, L.

1995. The Contemporary Challenge of St John of the Cross. An Introduction to his Life and Teaching. Washington, D.C.: ICS Publications.

FLYNN, M.

1996. The Spiritual Uses of Pain in Spanish Mysticism. Journal of the American Academy of Religion, LXIV (2): 257-278.

Freeman, M.

1993. Rewriting the Self. History, Memory, Narrative. London and New York: Routledge.

Howells, E.

2002. John of the Cross and Teresa of Avila. Mystical Knowing and Selfhood. New York: Crossroad.

Kavanaugh, K. \& Rodriguez, O.

1979. The Collected Works of St John of the Cross. Translated by Kieran Kavanaugh and Otilio Rodriguez, with Introductions by Kieran Kavanaugh. Washington, D.C.: ICS Publications.

Kourie, C.

1993. Myth and Mysticism. In: M. Clasquin, J. Ferreira-Ross, D. Marais \& R. Sadowsky (eds.) Myth and Interdisciplinary Studies. (Pretoria: UNISA Press), pp. 109-131.

Kurian, A.

2000. Ascent to Nothingness. The Ascent to God according to John of the Cross. A. Tulloch (ed.) London, St Pauls.

Matthew, I. 1995. The Impact of God. Soundings from St John of the Cross. London: Hodder \& Stoughton.

Maclntyre, A.

1990. Three Rival Versions of Moral Enquiry. Encyclopaedia, Genealogy, and Tradition. Notre Dame, Indiana: University of Notre Dame Press.

2009. Od, Philosophy, Universities. A Selective History of the Catholic Philosophical Tradition. Lanham, Maryland: Rowman and Littlefield. 
MCDERMOTT, T. (ED.) 1989. St Thomas Aquinas. Summa Theologiae. Concise Translation. Westminster, Maryland: Christian Classics.

McGreaL, W. 1996. John of the Cross. London: HarperCollins.

McINTOSH, M.A. 1998. Mystical Theology. The Integrity of Spirituality and Theology. Oxford: Blackwell.

PARFIT, D. 2011. On What Matters. Volume One. Edited and Introduced by Samuel Scheffler. Oxford: Oxford University Press.

Pieper, J.

1960. Scholasticism. Personalities and Problems of Mediaeval Philosophy. Faber and Faber.

Ridderbos, $\mathrm{H}$.

1975. Paul. An Outline of His Theology. Translated by John Richard De Witt. Grand Rapids: Eerdmans.

TURNER, D.

1995. The Darkness of God. Negativity in Christian Mysticism. Cambridge: Cambridge University Press.

TURNER, D.

2011. Julian of Norwich, Theologian. New Haven and London: Yale University Press.

VAN ECK, P. \& ENGLAND, F.

1990. The Way of Dispossession:Modern Theology Engages with a Saint. Journal of Theology for Southern Africa 73: 60-66.

WANAMAKER, C.A. 1990. The Epistles to the Thessalonians. A Commentary on the Greek Text. Grand Rapids: Eerdmans.

$\begin{array}{ll}\text { Keywords } & \text { Trefwoorde } \\ \text { Desire } & \text { Begeerte } \\ \text { Imagination } & \text { Verbeelding } \\ \text { Fantasy } & \text { Fantasie } \\ \text { Memory } & \text { Geheue } \\ \text { Intellect } & \text { Intellek } \\ \text { Will } & \text { Wil }\end{array}$

